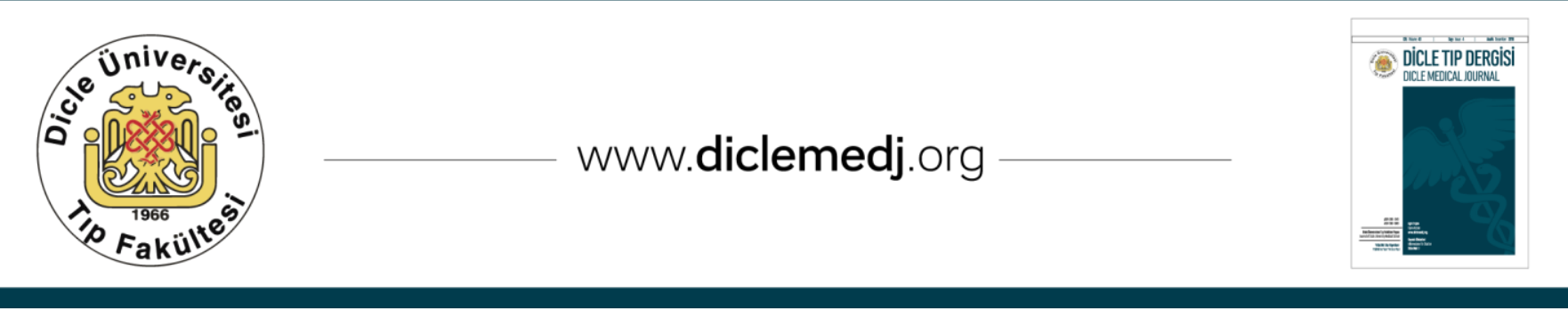

Olgu Sunumu / Case Report

\title{
Nekrotizan Fasiit: Vitamin D eksikliği predispozan bir faktör olabilir mi? Olgu sunumu
}

\author{
Mervan Bekdaş ${ }^{1}$, Ali Gökkaya ${ }^{2}$ \\ 1 Abant İzzet Baysal Üniversitesi Tıp Fakültesi Çocuk Sağlığı ve Hastalıkları Anabilim dalı, Bolu, Türkiye ORCID: 0000-0003-2469-9509 \\ 2 Abant İzzet Baysal Üniversitesi Tip Fakültesi Plastik ve Rekonstrüktif Cerrahi Anabilim dalı, Bolu, Türkiye ORCID: 0000-0003-2710-9615
}

Geliş: 10.01.2019; Revizyon: 08.04.2019; Kabul Tarihi: 10.05.2019

Öz

Nekrotizan Fasiit (NF), subkutan doku ve fasiya nekrozu ile kendini gösteren bakteriyel bir yumuşak doku enfeksiyonudur. Hızlı ilerleyen bir tablo olması nedeniyle erken tanı hayat kurtarıcıdır. Daha önceden sağlıklı olan 12 aylık kız hasta 2 gün önce başlayan ateş, sağ kasık bölgesinde kızarıklık ve şişlik nedeniyle hastanemize getirildi. Başlanan uygun tedaviye rağmen lezyonlar iki taraflı lomber bölge, sırt ve gögüs yan duvarına yayılınca hastada nekrotizan fasiit düşünüldü, takibinin 36. saatinde fasiyotomi insizyonu ile tüm nekrotik dokuların drenajı yapıldı. Uyluk fasiyo-kutan flepler defektlerin onarımı için kullanıldı. $25(\mathrm{OH})$ vitamin D seviyesi $2.4 \mathrm{ng} / \mathrm{ml}$ saptanınca 10.000 IU/kg D vitamini oral yoldan verildi. 16. gününde hasta taburcu edildi. 4. ayındaki kontrolde yaraların belirgin olarak düzeldiği görüldü.

Antimikrobiyal aktivitesi olan D vitamininin, yara iyileşmesini de hızlandıran bir özelliği olduğu kabul edilmektedir. Hastamızda D vitamini replasmanının iyileşmeyi olumlu yönde etkilediğine inanıyoruz. Değişik predispozan risk faktörleri olmasına rağmen, literatürde vitamin D eksikliği ile ilişkili NF'ye dair bir yayın tespit edemedik. Vitamin D eksikliğinin de NF için kolaylaştırıcı bir faktör olabileceğine dikkat çekmek için bu olguyu sunmayı amaçladık.

Anahtar kelimeler: Nekrotizan Fasiit, Vitamin D, Çocuk.

DOI: $10.5798 /$ dicletip.

Yazışma Adresi / Correspondence: Mervan Bekdaş, Abant İzzet Baysal Üniversitesi, Tıp Fakültesi, Çocuk Sağlığı ve Hastalıkları AD, Bolu, Türkiye e-mail: merbek14@yahoo.com 


\title{
Necrotizing fasciitis: Is vitamin D deficiency a predisposing factor? Case report
}

\begin{abstract}
Necrotizing fasciitis (NF) is a bacterial soft tissue infection characterized by necrosis of subcutaneous tissue and fascia. Because of its rapid progression, early diagnosis of NF is life-saving. A previously healthy 12-month-old female presented at our hospital with a two-day history of fever, rush and swelling in the right groin. Despite the appropriate treatment, NF was considered when the lesions spread to the lateral wall of the bilateral lumbar region, back and chest side wall. At the 36th hour of follow-up, all necrotic tissues were drained by fasciotomy incision. Thigh fasciocutaneous flaps were used for reconstruction of defects. Vitamin D (10,000 IU/kg) was given orally when 25 (OH) vitamin D levels were determined as $2.4 \mathrm{ng} / \mathrm{ml}$. She was discharged on the 16th day. At the 4th month of follow-up, wounds were seen markedly improved.

Vitamin D, which is an antimicrobial activity, is considered to be a feature that accelerates wound healing. We believe vitamin D replacement has a positive effect on healing of our patient. Although different predisposing risk factors, we could not determine any information about NF associated with vitamin D deficiency in the literature. We aimed to present this case report to attract attention vitamin D deficiency may also be a facilitatory factor for NF.
\end{abstract}

Keywords: Necrotizing Fasciitis, Vitamin D, Child.

\section{GİRIŞ}

Nekrotizan fasit (NF), hayatı tehdit eden bir yumuşak doku enfeksiyonudur. Temelde subkutan dokular etkilenir, fasiya nekrozu da hastalığın değișmez bir bulgusudur ${ }^{1}$. Pediatrik $\mathrm{NF}$ nadir görülen bir hastalıktır, prevalansının yüzbinde 0,08 olduğu tahmin edilmektedir ${ }^{2}$. Erişkinlerin aksine, NF gelişen çocukların çoğu tablo öncesinde sağlıklı olan bireylerdir, hastalığın başlaması için sıklıkla minör bir lezyon yeterlidir ${ }^{1}$.

Hızlı ilerleyen bir tablo olması nedeniyle erken tanı hayat kurtarıcıdır. Ancak hastalığın nadir olması ve hastalığa özgü patognomonik bulgunun olmaması tanının gecikmesine neden olmaktadır. Geç tanıyı engellemenin en önemli yolu, uygun hastalarda hekimin NF tanı eşiğini düşük tutmasıdır. Hastalığın çocukluk çağındaki mortalitesi \%5 civarındadır. Tanı ve uygun tedavinin başlanmasındaki gecikmeler mortaliteyi arttıran en önemli nedenlerdir ${ }^{1,3}$.

D vitamini, primer olarak kalsiyum homeostazı ve kemik metabolizmasından sorumlu olmakla birlikte; bu vitamine ait reseptörler birçok hücre üzerinde gösterilmiştir. Aktive edilmiş $\mathrm{CD} 4+$ ve CD8+ $\mathrm{T}$ lenfositler, $\mathrm{B}$ lenfositler, nötrofiller ve antijen sunan hücreler (makrofajlar ve dendritik hücreler) dâhil olmak üzere hemen hemen tüm bağışıklık sistemi hücreleri üzerinde de D vitamini reseptörleri gösterilmiştir4. Bu özellik, D vitamini eksikliğinde enfeksiyon hastalıklarının artmasının nedenini açıklamaktadır 5 .

NF için çeşitli predispozan risk faktörleri vardır, ancak literatürde vitamin D eksikliğinin eşlik ettiği bir NF olgusu saptanmamıştır. NF'de vitamin D eksikliğine dikkat çekmek için bu olguyu sunmayı amaçladık.

\section{OLGU}

(Hastanın yasal temsilcisine "bilgilendirilmiş gönüllü olur" belgesi imzalatılmıștır)

Daha önceden sağlıklı olan bir yaşındaki kız hasta 2 gün önce başlayan ateș, öksürük, sağ kasık bölgesinde kızarıklık ve şişlik nedeniyle hastanemize getirildi. Fizik muayenesinde vücut ağırlığı $10 \mathrm{~kg}$ (50.persantil), boyu $77 \mathrm{~cm}$ (50-75.persantil), vücut 1 sısı $38.9^{\circ} \mathrm{C}$ (aksiler), kalp tepe atımı 165/dakika (ritmik), solunum sayısı 42/dakika (düzenli), kan basıncı 95/60 mmHg idi. Genel durumu kötü olan hastanın kapiller dolum zamanı 5 saniye idi, sağ inguinal bölge derisinde eritemli, ödemli ve sinırları net olmayan pasif hareketlerle ağrılı bir lezyon 
mevcuttu. Her iki hemitoraksta raller dışında tüm sistem bulguları doğaldı. Laboratuvar incelemesinde; Hemoglobin $8.4 \mathrm{~g} / \mathrm{dl}$, lökosit sayıs $8900 / \mathrm{mm} 3$, trombosit sayısı 289000/mm3, C reaktif protein (CRP) 166 $\mathrm{mg} / \mathrm{dl}$ idi.

Biyokimyasal incelemede sodyum $125 \mathrm{mEq} / \mathrm{l}$, potasyum $4,2 \mathrm{mEq} / \mathrm{l}$, kalsiyum $7.9 \mathrm{mg} / \mathrm{dl}$ iken, karaciğer ve böbrek fonksiyon testleri normaldi. Kan gazında pH 7.4, pCO2 $21 \mathrm{mmHg}$, HCO3 13mEq/l, laktat $5 \mathrm{mEq} / \mathrm{l}$ olarak saptandı. Akciğer grafisi normaldi. Lezyonun yüzeyel ultrasonografisinde (USG) cilt altında yoğun kalınlık ve ekojenite artışı dışında patolojik bulgu saptanmadı. Selülit ve sepsis tanılarıyla kültürleri alındıktan sonra hastaya $77 \mathrm{mEq} / \mathrm{l}$ sodyum içeren IV mayi, $120 \mathrm{mg} / \mathrm{kg}$ meropenem IV ve $60 \mathrm{mg} / \mathrm{kg}$ vankomisin IV tedavileri başland. Tedaviye rağmen lezyonlar sol inguinal ve lomber bölge, sirt ve göğüs yan duvarına yayılınca hastada nekrotizan fasiit düşünüldü, takibinin 36. saatinde fasiyotomi insizyonu ile tüm nekrotik dokuların drenajı ve eksizyonu yapıldı (Resim 1).

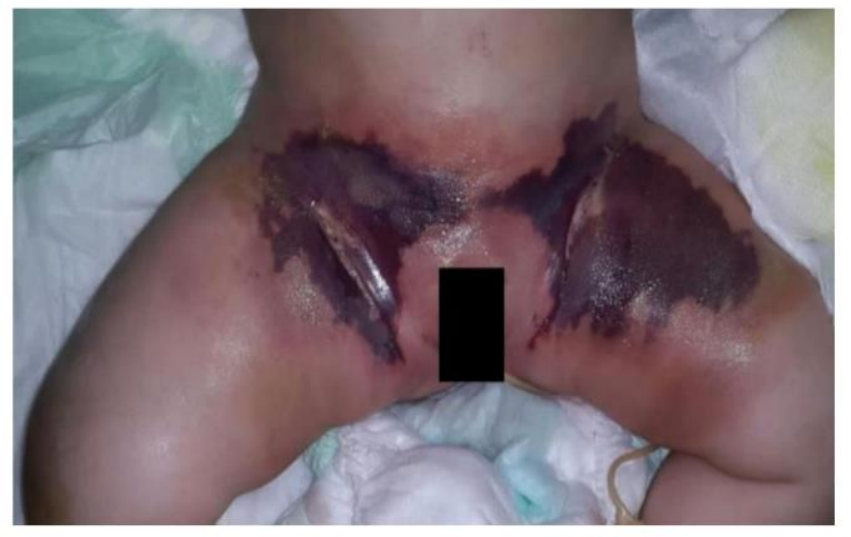

Resim 1:Fasyotomi insizyonu sonrası görünüm

D vitamini eksikliğine ait fizik muayene bulgusu olmamasına rağmen hipokalsemi saptanınca ek tetkikleri istendi, fosfor $2.2 \mathrm{mg} / \mathrm{dl}$, ALP $462 \mathrm{IU} / \mathrm{l}$, $25(\mathrm{OH})$ vitamin D 2.4ng/ml ve PTH 132,1 $\mathrm{pg} / \mathrm{ml}$ bulununca hastaya tedavinin üçüncü gününde 10.000 Ü/kg D vitamini oral yoldan verildi. Genel durumu düzelince hastanın her iki uyluğundan fasiyo-kutan flepler kaldırıldı ve defekt onarıldı. Yara kültüründe Stafilokokus Aureus üredi. Genel durumu, fizik muayene ve laboratuvar patolojileri düzelen hastanın antibiyotikleri 10. günde kesildi. Hasta takibinin 16. gününde idame dozda $\mathrm{D}$ vitamini ile taburcu edildi. Düzensiz olarak kontrollere getirilen hasta en son 4. ayında görüldügünde belirgin olarak düzeldiği görüldü (Resim 2).

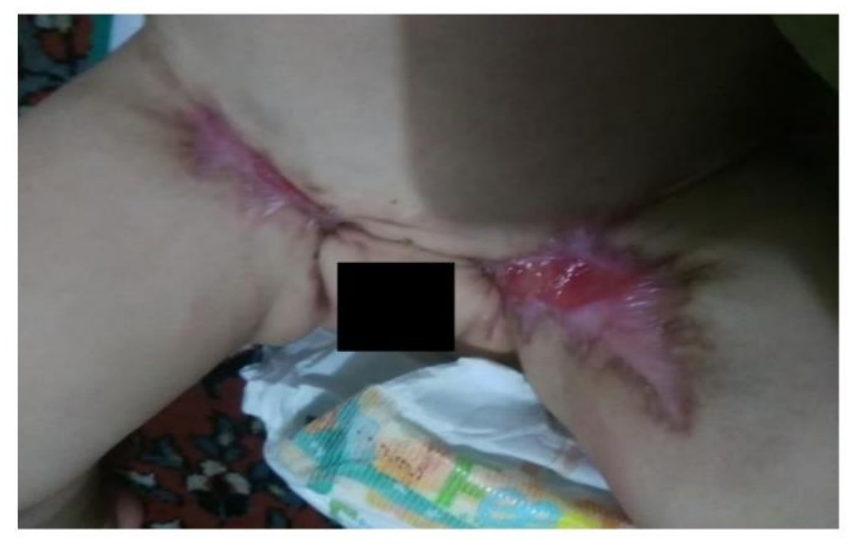

Resim 2: Fasyo-kutan flepler ile defekt kapatıldıktan sonraki görünüm

\section{TARTIŞMA}

$\mathrm{NF}$, progresif subkutan doku ve fasiya nekrozu ile giden, ölümcül bir bakteriyel yumuşak doku enfeksiyonudur. Genellikle polimikrobiyal özellikte olup, en sık izole edilen mikroorganizma türleri Stafilokok, Streptokok, Klebsiella ve E. Coli'dir ${ }^{1}$. Lezyonlar vücudun herhangi bir yerinde başlayabilir. Yapılan çalışmalarda primer lezyon \%33-44 olguda alt ekstremitede, \%33 olguda perinede, \%22-25 olguda yüz-boyunda, \%8-19 olguda üst ekstremitede, \%8 olguda göğüste ve $\% 8$ olguda da abdominal bölgede saptanmıştır ${ }^{3,6}$.

En erken semptomlar ateş, eritem ve lokalize şişliktir. NF'nin başlangıç aşamasında hafif görünümlü cilt lezyonlarına oranla şiddetli ağrı saptanmaktadır, bu tip bir ağrı NF'nin tipik klinik belirtisi olarak kabul edilmektedir1.

Pediatrik NF'nin erken tanısı için öykü ve fizik muayeneden sonra öncelikle CRP değerlendirilmeli, değerin $>20 \mathrm{mg} / \mathrm{dl}$ olduğu vakalarda sodyum değerine bakılmalıdır. $\mathrm{CRP}>20 \mathrm{mg} / \mathrm{dl}$ ve serum sodyum $<135 \mathrm{mEq} / \mathrm{l}$ 
olması pediatrik NF'yi öngörmede oldukça etkili bulunmuş, klinisyeni acil bir operasyon için uyarması gerektiği ifade edilmiştir7.

Direkt grafi, USG, Bilgisayarlı Tomografi ve Magnetic Resonance Imaging, NF tanısında kullanılan radyolojik görüntüleme yöntemleridir, subkutan alanda serbest havanın varlığı bu tetkiklerle saptanabilecek en önemli bulgudur ${ }^{1,2}$.

NF'nin tedavisi sıvı-elektrolit ve geniş spektrumlu antibiyotikler ile erken debridmandan oluşmaktadır ${ }^{1}$. Medikal tedavi ile beraber uygulanan cerrahi tedavi hayat kurtarıcıdır. Cerrahi tedavide, geniş fasiyotomi insizyonu ve fasiyal planlarin eksplorasyonu ile tüm nekrotik dokuların drenajı ve eksizyonu yapılmaktadır. Cerrahi tedavinin erken uygulanması çok önemlidir, bu tedavinin geciktirilmesi mortaliteyi belirgin olarak arttırmaktadır $^{1}$. Çoğu hastada multiple cerrahi girişim ihtiyacı olmaktadır ${ }^{2,3,8}$. Bunun haricinde olguların \%17'sinde cilt grefti ve \%25'inde de flap ihtiyacı olabilmektedir ${ }^{6}$.

NF için en sık tespit edilen predispozan faktörler sünnet, suçiçeği, inguinal herni operasyonu, omfalit, ekstremite lezyonu, perineal infeksiyon ve baş-boyun lezyonları gibi minör lezyonlar, pnömoni, sinüzit ve obezite olarak tespit edilmiştirir,2,6. Literatürde NF'ye vitamin D eksikliğinin eşlik ettiğine dair bir yayın tespit edemedik.

Monosit ve makrofajlar, sahip oldukları Tolllike reseptörleriyle tehlikeli patojenlere karşı ilk basamak savunmayı sağlayan, doğal bağışıklık sisteminin en önemli üyeleridir, bu hücrelerin salgıladığı en önemli antimikrobiyal peptidlerden olan kathelisidinlerin indüksiyonu için de bu reseptörlerin gerekli olduğu gösterilmiştir ${ }^{9}$. D vitamin düzeyi düşük olgularda enfeksiyon hastalıklarındaki artışın, kathelisidin sentezinin azalmasına bağlanmıştır 5 .
D vitamini düzeyi düşük olgularda makrofajların kemotaktik ve fagositik kapasitelerinin bozulmasına bağlı olarak enfeksiyon hastalıklarında artış olmaktadır ${ }^{10}$. Aktif D vitamini, yabancl antijenlerin dendritik hücreler tarafından tanınması ve yakalanmasında da önemli rol oynar, bunu da antijeni yakalayan mannoz reseptör ekspresyonunu arttırarak gösterir.

D vitamini düzeyinin düşüklüğü, bu fonksiyonların da bozulmasına neden olur ${ }^{11}$. Vitamin D eksikliğinde nukleer faktör- $\kappa B$ yolu aktifleşir, bu yolla pro-inflamatuvar sitokinler (IL-1 $\beta$, IL-6 ve TNF- $\alpha$ ) artar, yaraların iyileşmesindeki gecikmenin temel nedeni budur. D vitamini tedavisi verilen vakalarda da nukleer faktör- $\kappa B$ yolu supresyonu yoluyla yaraların daha kısa sürede iyileștiği gösterilmiştir ${ }^{12}$. Aktif $\mathrm{D}$ vitamininin immun sistem ve yara iyileşmesi üzerine olan bu etkileri nedeniyle, D vitamin eksikliğini olgumuzda tabloyu ağırlaştıran ek bir faktör olarak kabul ettik.

\section{SONUÇ}

Nekrotizan fasiitli hastaların tedavisi sırasında serum vitamin D seviyeleri de bakılmalıdır, eksikliğinin tespit edildiği hastalara D vitamininin, immun sistem ve yara iyileşmesi üzerine olan olumlu etkileri nedeniyle tedavi dozunda verilmesini öneriyoruz. Vitamin D eksikliği ile nekrotizan fasiit arasındaki ilişkiyi inceleyen daha geniş çaplı çalışmalara ihtiyaç vardir.

Çıkar Çatışması Beyanı: Yazarlar çıkar çatışması olmadığını bildirmişlerdir.

Finansal Destek: Bu çalışma her hangi bir fon tarafından desteklenmemiştir.

Declaration of ConflictingInterests: The authors declare that they have no conflict of interest.

Financial Disclosure: No financial support was received. 


\section{KAYNAKLAR}

1. Bayer ML, Drolet BA. Disorders of the Mucous Membranes, In: Kliegman RM, Stanton BF, St Gemell JW, Schor NF. eds. Nelson Textbook of Pediatrics 20th ed. Philadelphia, PA: Elsevier Saunders 2016; 3205-6.

2. Kumar M, Meeks A, Kearl L. Necrotizing Fasciitis of the Chest Wall: Report of Pediatric Cases. Pediatr Emer Care 2015; 31: 656-60.

3. Eneli I, Davies HD. Epidemiology and outcome of necrotizing fasciitis in children: an active surveillance study of the Canadian Paediatric Surveillance Program. J Pediatr 2007; 151: 79-84.

4. Takahashi K, Nakayama Y, Horiuchi $\mathrm{H}$, et all. Human neutrophils express messenger RNA of vitamin D receptor and respond to 1alpha,25- dihydroxyvitamin D3. Immunopharmacol Immunotoxicol 2002; 24: 33547.

5. White JH. Vitamin D as an inducer of cathelicidin antimicrobial peptide expression: past, present and future. J Steroid Biochem Mol Biol 2010; 121: 234-8.

6. VanderMeulen H, Pernica JM, Roy M, et all. A 10-Year Review of Necrotizing Fasciitis in the Pediatric Population: Delays to Diagnosis and Management. Clin Pediatr 2016;1-7. DOI: 10.1177/0009922816667314.
7. Putnam LR, Richards MK, Sandvall BK, et all. Laboratory evaluation for pediatric patients with suspected necrotizing soft tissue infections: A casecontrol study. J Pediatr Surg 2016; 51: 1022-25.

8. Şahiner İT, Kendirci M, Dolapçı M. Son bir yıl içindeki nekrotizan fasiitis tanısı alan hastaların değerlendirilmesi. Dicle Med J 2017; 44: 271-6.

9. Krutzik SR, Hewison M, Liu PT, et all. IL-15 links TLR2/1-induced macrophage differentiation to the vitamin D-dependent antimicrobial pathway. J Immunol 2008; 181: 7115-20.

10. $\mathrm{Xu} \mathrm{H}$, Soruri A, Gieseler RK, et all. 1,25Dihydroxyvitamin D3 exerts opposing effects to IL-4 on MHC class-II antigen expression, accessory activity, and phagocytosis of human monocytes. Scand J Immunol 1993; 38: 535-40.

11. Piemonti L, Monti P, Sironi M, et all. Vitamin D3 affects differentiation, maturation, and function of human monocyte-derived dendritic cells. J Immunol 2000; 164: 4443-51.

12. Yuan YF, Das SK, Li M. Vitamin D ameliorates impaired wound healing in streptozotocin-induced diabetic mice by suppressing NF- $\mathrm{BB}$-mediated inflammatory genes. Biosci Rep 2018; 38: BSR20171294. 